\title{
Hydrothermal Preparation of a Gehlenite Hydrate
}

\author{
Elmer T. Carlson
}

\author{
(May 11, 1964)
}

\begin{abstract}
Hydrothermal treatment of synthetic gehlenite $\left(2 \mathrm{CaO} \cdot \mathrm{Al}_{2} \mathrm{O}_{3} \cdot \mathrm{SiO}_{2}\right)$ or of various mixtures of oxides, hydrates, etc., approximating the composition of gehlenite, at 260 to $650^{\circ} \mathrm{C}$, produced a hitherto unreported compound having the composition $2 \mathrm{CaO} \cdot \mathrm{Al}_{2} \mathrm{O}_{3} \cdot \mathrm{SiO}_{2} \cdot \mathrm{H}_{2} \mathrm{O}$. Other phases, usually hydrogarnet, were always present in small amounts. A natural gehlenite containing $\mathrm{Fe}_{2} \mathrm{O}_{3}$ and $\mathrm{MgO}$ was partly converted to the same hydrate at $450^{\circ} \mathrm{C}$. The compound $2 \mathrm{CaO} \cdot \mathrm{Al}_{2} \mathrm{O}_{3} \cdot \mathrm{SiO}_{2} \cdot 8 \mathrm{H}_{2} \mathrm{O}$ was converted to a hydrogarnet at $250^{\circ} \mathrm{C}$, but formed $2 \mathrm{CaO} \cdot \mathrm{Al}_{2} \mathrm{O}_{3} \cdot \mathrm{SiO}_{2} \cdot \mathrm{H}_{2} \mathrm{O}$ at $35 \mathrm{C}{ }^{\circ} \mathrm{C}$. The new compound has a body-centered cubic structure, with $a_{0}=8.83 \AA$. The index of refraction is 1.628 . An x-ray diffraction pattern is given, and some similarities between $\mathrm{CaO} \cdot \mathrm{Al}_{2} \mathrm{O}_{3} \cdot \mathrm{SiO}_{2} \cdot \mathrm{H}_{2} \mathrm{O}$ and the ternary compound $4 \mathrm{CaO} \cdot 3 \mathrm{Al}_{2} \mathrm{O}_{3}-$ $.3 \mathrm{H}_{2} \mathrm{O}$ are pointed out.
\end{abstract}

\section{Introduction}

The mineral gehlenite is of relatively uncommon occurrence in nature, but is a common constituent of air-cooled blast-furnace slags and is present in some high-alumina cements [1]. ${ }^{1}$ The ideal formula is $2 \mathrm{CaO} \cdot \mathrm{Al}_{2} \mathrm{O}_{3} \cdot \mathrm{SiO}_{2}$, but other oxides, particularly $\mathrm{MgO}$ and $\mathrm{Fe}_{2} \mathrm{O}_{3}$, may be present in solid solution, forming a group of minerals known as melilites. From a practical standpoint, gehlenite usually has been considered a useless constituent of cements and slags, since it reacts very slowly with water and does not have cementitious properties [1]. There is evidence, however, that glasses having the oxide composition of gehlenite are more reactive with water than is the crystalline mineral. It has been shown by Locher [2] that vitreous slags in the gehlenite area of the system $\mathrm{CaO}-\mathrm{Al}_{2} \mathrm{O}_{3}-\mathrm{SiO}_{2}$ develop cementitious properties when activated with lime, cement, or anhydrite.

The cementitious properties of such slags have been attributed, at least in part [2], to the so-called gehlenite hydrate, $2 \mathrm{CaO} \cdot \mathrm{Al}_{2} \mathrm{O}_{3} \cdot \mathrm{SiO}_{2} \cdot 8 \mathrm{H}_{2} \mathrm{O}$, crystallizing as hexagonal plates. This compound was first prepared by Strätling, whose work was reported by Büssem [3] at the Symposium on the Chemistry of Cements (Stockholm, 1938). It has since been prepared by several investigators, including the author, from various starting materials, at temperatures ranging from 1 to $50{ }^{\circ} \mathrm{C}$. Early attempts to prepare it from gehlenite were unsucccessful. The application of hydrothermal treatment to speed up the hydration resulted in formation of a hydrogarnet [4]. Crystallographic studies $[5,6]$ indicate that there is no close structural relationship between gehlenite (crystallizing in the tetragonal system [1]) and the so-called gehlenite hydrate.

During the course of some hydrothermal studies in the system $\mathrm{CaO}-\mathrm{Al}_{2} \mathrm{O}_{3}-\mathrm{SiO}_{2}-\mathrm{H}_{2} \mathrm{O}$, the author observed a series of unidentified $\mathrm{x}-\mathrm{r}$ ay diffraction lines in the

\footnotetext{
${ }_{1}$ Figures in brackets indicate the literature references at the end of this paper.
}

powder patterns of several preparations. The present paper gives the results of experimental work leading to the conclusion that the new pattern is produced by a hitherto unreported "gehlenite hydrate," having the composition $2 \mathrm{CaO} \cdot \mathrm{Al}_{2} \mathrm{O}_{3} \cdot \mathrm{SiO}_{2}$. $\mathrm{H}_{2} \mathrm{O}$ and crystallizing in the cubic system.

\section{Materials and Procedures}

The primary starting materials were reagent grade silicic acid, aluminum hydroxide, and calcium carbonate (low alkali). Glasses of various compositions were prepared by heating the mixed raw materials, in the desired proportions, in an electric furnace. Several preparations were heated below the fusion temperature; these are referred to below as "sinters." Synthetic gehlenite was prepared in this manner by heating the properly proportioned materials at about $1460{ }^{\circ} \mathrm{C}$. The product appeared to be about 95 percent gehlenite by microscopic examination. The compound $2 \mathrm{CaO} \cdot \mathrm{Al}_{2} \mathrm{O}_{3} \cdot \mathrm{SiO}_{2} \cdot 8 \mathrm{H}_{2} \mathrm{O}$ was prepared in two ways: (1) by prolonged treatment of a mixture of calcium hydroxide and a lime-alumina-silica glass, in correct proportions, with water at room temperature; (2) by precipitation from a suspension of silicic acid in calcium aluminate solution, also at room temperature.

A sample of natural gehlenite originally from Tyrol was used for a few experiments. The rock was first crushed, treated with hydrochloric acid to remove most of a calcite int ergr owth, washed, dried, and pulverized before use. The x-ray diffraction pattern was in close agreement with that obtained from the synthetic gehlenite, except that the natural material showed additional weak lines due to calcite. Chemical analysis, however, revealed 1.8 percent of $\mathrm{Fe}_{2} \mathrm{O}_{3}$ and 3.7 percent of $\mathrm{MgO}$, indicating that the mineral dep art ed significantly from the ideal gehlenite composition.

With a few exceptions, the hydrothermal reactions were effected in 18-ml stainless-steel pressure vessels (Morey bombs), the reactants being held in small platinum crucibles. Pressure was estimated from the temperature and the amount of water present. 
TABLE 1. Hydrothermal experiments on gehlenite and related compositions

\begin{tabular}{|c|c|c|c|c|c|c|c|}
\hline $\begin{array}{l}\text { Expt. } \\
\text { No. }\end{array}$ & $\begin{array}{c}\text { Oxide ratio } \\
\mathrm{CaO}: \mathrm{Al}_{2} \mathrm{O}_{3}: \mathrm{SiO}_{2}\end{array}$ & Starting material & Temperature & Pressure a & Duration & $\begin{array}{l}\text { Relative amount } \\
\text { of isometric } \\
\text { phase } b \text { present }\end{array}$ & Other phases present $\mathrm{b} e$ \\
\hline & & & ${ }^{\circ} \mathrm{C}$ & atm & Days & & \\
\hline 1 & $2: 1: 1$ & Sinter $\ldots$ & 182 & 10 & 37 & nd. & $\mathrm{hg}(\mathrm{s}) ; \operatorname{boh}(\mathrm{m})$ \\
\hline 2 & $2: 1: 1$ & do & 260 & 45 & 37 & $\mathrm{~m}_{--}$ & $\operatorname{boh}(s) ; h g(s)$ \\
\hline 3 & $2: 1: 1$ & Synth. gehlenite....... & 332 & 125 & 20 & vs... & $\operatorname{geh}(\mathrm{m}) ; \operatorname{hg}(\mathrm{w}) ; \operatorname{boh}(?)$ \\
\hline 4 & $2: 1: 1$ & Sinter & 350 & 160 & 16 & VS.-. & $\mathrm{hg}(\mathrm{w})$ \\
\hline 5 & $2: 1: 1$ & Synth. gehlenite & 405 & 300 & 16 & vs... & geh (s) \\
\hline 6 & $2: 1: 1$ & Sinter & 446 & 400 & 16 & $\mathrm{vS}_{-}$ & $h g(v w)$ \\
\hline 7 & $2: 1: 1$ & Synth. gehlenite & 650 & 2040 & $\begin{array}{r}10 \\
3\end{array}$ & vs.- & geh (vw) \\
\hline 8 & $2: 1: 1$ & do & 750 & 2040 & 3 & nd. & geh(vs) \\
\hline 9 & $2: 1: 1$ & Natural gehlenite & 348 & 160 & 11 & nd. & $\mathrm{hg}(\mathrm{s})$ \\
\hline 10 & $2: 1: 1$ & _..._do do............... & 402 & 290 & 7 & $?$ & hg(vs) \\
\hline 11 & $2: 1: 1$ & do & 450 & 400 & 11 & $\mathrm{~m}$ & $\mathrm{hg}(\mathrm{w})$ \\
\hline 12 & $2: 1: 1$ & $2 \mathrm{CaO} \cdot \mathrm{Al}_{2} \mathrm{O}_{3} \cdot \mathrm{SiO}_{2} \cdot 8 \mathrm{H}_{2} \mathrm{O}$ & 150 & 5 & 34 & nd. & $\mathrm{C}_{2} \mathrm{ASH}_{8}(\mathrm{vs}) ; \mathrm{hg}(\mathrm{m})$ \\
\hline 13 & $2: 1: 1$ & do & 250 & 40 & 34 & nd- & $\mathrm{hg}(\mathrm{s}) ; \operatorname{boh}(\mathrm{s})$ \\
\hline 14 & $2: 1: 1$ & do & 350 & 160 & 31 & vs.- & $\mathrm{hg}(\mathrm{vw})$ \\
\hline 15 & $2: 1: 1$ & Mixed oxides & 346 & 150 & 36 & vs.- & $\mathrm{hg}(\mathrm{w})$ \\
\hline 16 & $2: 1: 1 \ldots$ & _.... do _... & 450 & 420 & 35 & $\mathrm{VS}_{-}$ & $\mathrm{hg}(\mathrm{w})$ \\
\hline 17 & $1.26: 1: 1$ & Glass & 382 & 235 & 21 & $\mathrm{~S}_{-.-}$ & hg(vs); boh(s) \\
\hline 18 & $1.5: 1: 1$ & Sinter ... & 350 & 160 & 135 & $\mathrm{~m}_{-}$ & $\mathrm{hg}(\mathrm{s}) ; \operatorname{boh}(\mathrm{w})$ \\
\hline 19 & $2.5: 1: 1$ & - do & 406 & 300 & 14 & vS & $\mathrm{Ca}(\mathrm{OH})_{2}(\mathrm{~s})$ \\
\hline 20 & $3: 1: 1$ & Glass+Ca $(\mathrm{OH})_{2}$ & 355 & 170 & 18 & vs... & $\mathrm{Ca}(\mathrm{OH})_{2}(\mathrm{~s})$ \\
\hline 21 & $3: 1: 0.4$ & Glass & 365 & 190 & 14 & vs $_{-.}$ & $\mathrm{Ca}(\mathrm{OH})_{2}(\mathrm{vs}) ; \mathrm{C}_{4} \mathrm{~A}_{3} \mathrm{H}_{3}(\mathrm{~s})$ \\
\hline 22 & $3: 1: 1.2$ & . do & 371 & 210 & 18 & $\mathrm{~S}_{\ldots} \ldots$ & $\mathrm{hg}(\mathrm{m}) ; \mathrm{Ca}(\mathrm{OH})_{2}(\mathrm{w})$ \\
\hline 23 & $3: 1: 2$ & Glass (devitrified) & 350 & 160 & 52 & $\mathrm{~m}_{--}$ & $\mathrm{hg}(\mathrm{s})$ \\
\hline 24 & $3: 1: 2$ & _ _ do & 448 & 420 & 15 & $\mathrm{~m}_{-}$ & $\mathrm{hg}(\mathrm{w})$ \\
\hline 25 & $3: 1: 2$ & do & 570 & 1020 & $1 / 4$ & $\mathrm{~m}_{-}$ & $\mathrm{hg}(\mathrm{s})$ \\
\hline 26 & $3: 1: 2$ & Dehyd. kaolin $+\mathrm{Ca}(\mathrm{OH})_{2}$ & 445 & 400 & 7 & $\mathrm{~m}_{-. .}$ & $\mathrm{hg}(\mathrm{s}) ; \mathrm{Ca}(\mathrm{OH})_{2}(\mathrm{w})$ \\
\hline 27 & $2: 1: 0.5$ & Sinter $+\mathrm{Ca}(\mathrm{OH})_{2}$ & 358 & 180 & 28 & $\mathrm{~S}_{\ldots} \ldots$ & $\mathrm{C}_{4} \mathrm{~A}_{3} \mathrm{H}_{3}(\mathrm{~s}) ; \mathrm{Ca}(\mathrm{OH})_{2}(\mathrm{w})$ \\
\hline 28 & $1.5: 1: 0.5$ & Sinter & 350 & 160 & 27 & vs.... & $\mathrm{C}_{4} \mathrm{~A}_{3} \mathrm{H}_{3}(\mathrm{~m}) ; \operatorname{boh}(\mathrm{w})$ \\
\hline 29 & $2.5: 1.5: 1$ & _ do do & 400 & 280 & 14 & VS & $\mathrm{C}_{4} \mathrm{~A}_{3} \mathrm{H}_{3}(\mathrm{~m})$ \\
\hline 30 & $4: 2.5: 1$ & 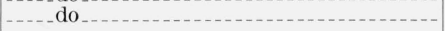 & 376 & 220 & 20 & vs & $\mathrm{C}_{4} \mathrm{~A}_{3} \mathrm{H}_{3}(\mathrm{w})$ \\
\hline
\end{tabular}

a Estimated from temperature and degree of filling, except for Nos. 7, 8, and 25. $\mathrm{b}$ Relative amounts of phases estimated from intensities of strongest $\mathrm{x}$-ray lines The symbols commonly used for relative intensities are here used to indicate estimated amounts of phases present. vs=very strong; $\mathrm{s}=$ strong; $\mathrm{m}=$ =medium;

Temperature was controlled to about $\pm 2{ }^{\circ} \mathrm{C}$. For hydrothermal treatment at temperatures above $500{ }^{\circ} \mathrm{C}$, a Tuttle cold-seal apparatus was used. Xray diffraction diagrams of the powdered preparations were obtained on a diffractometer, using $\mathrm{CuK} \alpha$ radiation.

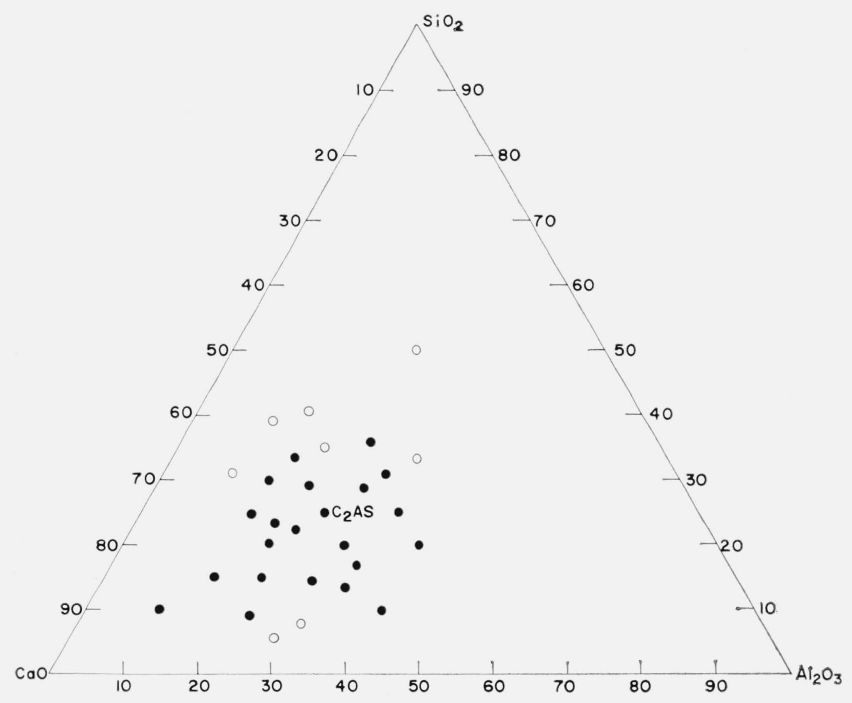

Figure 1. Compositions of compounds and mixtures given hydrothermal treatment, shown in relation to the anhydrous system $\mathrm{CaO}-\mathrm{Al}_{2} \mathrm{O}_{3}-\mathrm{SiO}_{2}$. (Plotted on molar basis)

Filled circles: new phase $\left(2 \mathrm{CaO} \cdot \mathrm{Al}_{2} \mathrm{O}_{3} \cdot \mathrm{SiO}_{2} \cdot \mathrm{H}_{2} \mathrm{O}\right)$ observed in product Open circles: new phase not observed in product.

$\mathrm{w}=$ weak; $\mathrm{vw}=$ very weak; ?=too weak for positive identification; $\mathrm{nd}=$ no detected.

c boh=boehmite; geh=gehlenite; hg=hydrogarnet; $\mathrm{C}_{4} \mathrm{~A}_{3} \mathrm{H}_{3}=4 \mathrm{CaO} \cdot 3 \mathrm{Al}_{2} \mathrm{O}_{3}$. $3 \mathrm{H}_{2} \mathrm{O} ; \mathrm{C}_{2} \mathrm{ASH}_{8}=2 \mathrm{CaO} \cdot \mathrm{Al}_{2} \mathrm{O}_{3} \cdot \mathrm{SiO}_{2} \cdot 8 \mathrm{H}_{2} \mathrm{O}$.

\section{Results}

The new isometric phase has been observed in more than 50 preparations obtained by hydrothermal treatment of various materials and mixtures, both hydrous and anhydrous, having compositions near the gehlenite region of the system $\mathrm{CaO}-\mathrm{Al}_{2} \mathrm{O}_{3}-\mathrm{SiO}_{2}$. The location of the various compositions with reference to the ternary diagram is shown in figure 1 . Table 1 gives data pertaining to a number of these preparations, selected to show the effects of temperature, composition, and the nature of the starting materials. Experiments 1 to 16 comprise a series in which the molar proportions $\mathrm{CaO}: \mathrm{Al}_{2} \mathrm{O}_{3}: \mathrm{SiO}_{2}$, were held at $2: 1: 1$. Two types of synthetic anhydrous starting materials were used. The one referred to as "sinter" had been heated at about $1040{ }^{\circ} \mathrm{C}$, which is far below the temperature at which complete reaction can be expected. The "synthetic gehlenite," in contrast, had been heated at $1460{ }^{\circ} \mathrm{C}$, and was estimated to be about 95 percent gehlenite. On hydrothermal treatment, both types yielded the same hydration products, but the material which had been heated only to $1040{ }^{\circ} \mathrm{C}$ react ed more rapidly with water than did the well-crystallized gehlenite. Formation of the new isometric phase occurred in the temperature range 260 to $650{ }^{\circ} \mathrm{C}$, but in no case was a pure product obtained. Small amounts of hydrogarnet were detected in most of the reaction products. Variation in the $\mathrm{x}$-ray line positions indicated an increase in the silica content of the hydrogarnet phase with increasing temperature, in agreement with results published previously [7]. 
The synthetic gehlenite was largely converted to the isometric hydrate by hydrothermal treatment at $650{ }^{\circ} \mathrm{C}$, but not at $750^{\circ} \mathrm{C}$. At the latter temperature the irregular gehlenite particles were transformed to well formed crystals, but the x-ray pattern indicated no alteration in structure.

The sample of natural gehlenite was partly converted to the isometric hydrate at $450{ }^{\circ} \mathrm{C}$, but not at $348{ }^{\circ} \mathrm{C}$, only the hydrogarnet phase being formed at the latter temperature. The difference in behavior between the natural and the synthetic materials may reasonably be attributed to the presence of other components in the natural mineral, as disclosed by analysis.

Experiments 12 to 14 , in which the hexagonal gehlenite hydrate was treated hydrothermally for about a month, are of interest for two reasons. First, the low temperature hydrate underwent little or no alteration at $150{ }^{\circ} \mathrm{C}$. A moderate amount of hydrogarnet was observed in the product, but the same phase was present in the starting material. Second, the low temperature hydrate was decomposed to hydrogarnet and boehmite at $250{ }^{\circ} \mathrm{C}$, indicating that it is not converted to the high temperature hydrate directly by loss of water. The new isometric phase was formed at $350{ }^{\circ} \mathrm{C}$.

Mixtures of the hydrated oxides (experiments 15 and 16) also produced the new phase along with small amounts of hydrogarnet.

The rest of the experiments listed in table 1 cover a range of oxide proportions other than $2: 1: 1$. In Nos. 17 and 18, with the proportion of $\mathrm{CaO}$ reduced, the new phase was accompanied by larger amounts of hydrogarnet and a considerable quantity of boehmite. In Nos. 19 and 20 the excess lime appeared as $\mathrm{Ca}(\mathrm{OH})_{2}$. In the remainder of the experiments listed, the proportions of all three solid components were varied. Here the phase relationships naturally became rather complex. No attempt was made to define phase boundries, as the primary purpose here was to ascertain what proportions of oxides gave the best yield of the new phase. It is evident that the $2: 1: 1$ composition satisfied this condition better than any other investigated.

The last three experiments listed were designed to explore the area between the compositions represented by the oxide proportions $2 \mathrm{CaO}: \mathrm{Al}_{2} \mathrm{O}_{3}: \mathrm{SiO}_{2}$ and $4 \mathrm{CaO}: 3 \mathrm{Al}_{2} \mathrm{O}_{3}$, which is of interest because of certain similarities between the new phase and the ternary compound $4 \mathrm{CaO} \cdot 3 \mathrm{Al}_{2} \mathrm{O}_{3} \cdot 3 \mathrm{H}_{2} \mathrm{O}$. The X-ray patterns indicated that botb phases were present in the products, with no detectable shift in position of the lines, and hence no evidence of solid solution.

The new isometric phase occurred typically as octahedral crystals, usually with rounded edges. Cubo-octahedra were also observed, and in some preparations some of the crystals were elongated into prisms. The index of refraction was found to be 1.628 \pm 0.003 .

The water content of five of the more nearly homogeneous preparations was determined from the loss on ignition. The results, in terms of moles of $\mathrm{H}_{2} \mathrm{O}$ per mole of $2 \mathrm{CaO} \cdot \mathrm{Al}_{2} \mathrm{O}_{3} \cdot \mathrm{SiO}_{2}$, ranged from 1.00 to 1.19 , averaging 1.08. Preparations judged to be the most nearly homogeneous had the lowest water contents. Most of the water was driven off between 550 and $750{ }^{\circ} \mathrm{C}$.

The X-ray diffraction pattern of one of the powdered preparations is given in table 2 . The pattern indicated a body-centered cubic structure, with $a_{0}=8.83 \AA$. A pattern of a new preparation of $4 \mathrm{CaO} \cdot 3 \mathrm{Al}_{2} \mathrm{O}_{3} \cdot 3 \mathrm{H}_{2} \mathrm{O}$ is also given in the table to show the similarities between the strongest lines of the two. Tungsten was used as internal standard in both cases. The pattern of $4 \mathrm{CaO} \cdot 3 \mathrm{Al}_{2} \mathrm{O}_{3} \cdot 3 \mathrm{H}_{2} \mathrm{O}$ is

TABLE 2. Interplanar spacings of $2 \mathrm{CaO} \cdot \mathrm{Al}_{2} \mathrm{O}_{u} \cdot \mathrm{SiO}_{2} \cdot \mathrm{H}_{2} \mathrm{O}$ and $4 \mathrm{CaO} \cdot 3 \mathrm{Al}_{2} \mathrm{O}_{3} \cdot 3 \mathrm{H}_{2} \mathrm{O}$

\begin{tabular}{|c|c|c|c|c|}
\hline \multicolumn{3}{|c|}{$2 \mathrm{CaO} \cdot \mathrm{Al}_{2} \mathrm{O}_{3} \cdot \mathrm{SiO}_{2} \cdot \mathrm{H}_{2} \mathrm{O}$} & \multicolumn{2}{|c|}{$4 \mathrm{CaO} \cdot 3 \mathrm{Al}_{2} \mathrm{O}_{3} \cdot 3 \mathrm{H}_{2} \mathrm{O}$} \\
\hline \multirow[t]{2}{*}{$h k l$} & $d$ & $I$ & $d$ & $I$ \\
\hline & $\begin{array}{r}\AA \\
4.42\end{array}$ & 7 & A & \\
\hline \multirow[t]{3}{*}{211} & 3. 607 & 93 & $\begin{array}{l}\text { 3. } 61 \\
\text { 3. } 50\end{array}$ & $\begin{array}{r}100 \\
9\end{array}$ \\
\hline & & & $\begin{array}{l}\text { 3. } 20 \\
\text { 3. } 274\end{array}$ & 81 \\
\hline & & & 3. 207 & 3 \\
\hline \multirow[t]{2}{*}{220} & 3. 122 & 9 & $\begin{array}{l}\text { 3. } 109 \\
\text { 3. } 029\end{array}$ & $\begin{array}{r}5 \\
28\end{array}$ \\
\hline & & & $\begin{array}{l}3.029 \\
2.849\end{array}$ & $\begin{array}{l}28 \\
51\end{array}$ \\
\hline \multirow[t]{2}{*}{310} & 2. 793 & 100 & 2. 797 & 66 \\
\hline & & & $\begin{array}{l}\text { 2. } 741 \\
\text { 2. } 614\end{array}$ & $\begin{array}{r}4 \\
11\end{array}$ \\
\hline \multirow[t]{3}{*}{222} & 2. 549 & 32 & $\begin{array}{l}2.014 \\
2.545\end{array}$ & $\begin{array}{l}11 \\
22\end{array}$ \\
\hline & & & 2.419 & 21 \\
\hline & & & 2. 386 & 5 \\
\hline 321 & 2.360 & 29 & $\begin{array}{l}\text { 2. } 354 \\
\text { 2. } 290\end{array}$ & $\begin{array}{r}8 \\
26\end{array}$ \\
\hline \multirow[t]{3}{*}{400} & 2. 208 & 15 & 2. 225 & $\begin{array}{l}26 \\
35\end{array}$ \\
\hline & & & 2. 182 & 4 \\
\hline & & & 2. 169 & 17 \\
\hline \multirow[t]{5}{*}{411} & 2081 & 42 & 2. 137 & 10 \\
\hline & 2.081 & 42 & 2. 088 & 37 \\
\hline & & & $\begin{array}{l}2.071 \\
\text { 2. } 066\end{array}$ & $\begin{array}{r}17 \\
5\end{array}$ \\
\hline & & & 2. 053 & $\begin{array}{l}5 \\
5\end{array}$ \\
\hline & & & 2. 019 & 2 \\
\hline \multirow[t]{3}{*}{420} & 1. 974 & 8 & 1. 986 & 3 \\
\hline & $1.9 / 4$ & 8 & 1. 970 & 8 \\
\hline & & & $\begin{array}{l}1.931 \\
1.914\end{array}$ & $\begin{array}{l}4 \\
8\end{array}$ \\
\hline 332 & 1. 882 & 4 & 1. 838 & 5 \\
\hline \multirow{2}{*}{422} & 1.801 & 1) & 1. 823 & 4 \\
\hline & & 12 & $\begin{array}{l}1.801 \\
1.776\end{array}$ & $\begin{array}{l}6 \\
4\end{array}$ \\
\hline \multirow[t]{5}{*}{510} & 1. 730 & 13 & 1. 738 & 6 \\
\hline & & & 1. 726 & 3 \\
\hline & & & 1. 681 & 5 \\
\hline & & & 1. 668 & 3 \\
\hline & & & $\begin{array}{l}1.643 \\
1.619\end{array}$ & $\begin{array}{l}4 \\
5\end{array}$ \\
\hline \multirow[t]{2}{*}{521} & 1. 611 & 10 & 1. 601 & 20 \\
\hline & & & 1. 597 & 9 \\
\hline \multirow{2}{*}{440} & 1. 550 & & 1. 572 & 44 \\
\hline & 1. 559 & 38 & $\begin{array}{l}\text { 1. } 552 \\
\text { 1. } 540\end{array}$ & $\begin{array}{r}30 \\
7\end{array}$ \\
\hline \multirow[t]{2}{*}{530} & 1. 513 & 21 & 1. 511 & 11 \\
\hline & & & 1. 486 & 5 \\
\hline 600 & 1. 470 & 7 & $\begin{array}{l}\text { 1. } 470 \\
1.466\end{array}$ & 5 \\
\hline \multirow[t]{3}{*}{611} & 1. 431 & 13 & $\begin{array}{l}1.400 \\
1.429\end{array}$ & $\begin{array}{l}6 \\
3\end{array}$ \\
\hline & & & 1. 416 & 3 \\
\hline & & & 1. 396 & 2 \\
\hline \multirow{4}{*}{$\begin{array}{l}541 \\
622\end{array}$} & 1. 362 & 4 & $\begin{array}{l}\text { 1. } 375 \\
1.367\end{array}$ & $\begin{array}{l}2 \\
5\end{array}$ \\
\hline & 1. 330 & 7 & $\begin{array}{l}1.368 \\
1.331\end{array}$ & 3 \\
\hline & & & 1. 308 & 2 \\
\hline & & & 1. 289 & 14 \\
\hline 710 & 1. 248 & 4 & 1. 224 & 3 \\
\hline & & & 1. 219 & 3 \\
\hline $\begin{array}{l}721 \\
642\end{array}$ & $\begin{array}{l}\text { 1. } 201 \\
179\end{array}$ & $\begin{array}{l}3 \\
3\end{array}$ & $\begin{array}{l}1.185 \\
1.170\end{array}$ & $\begin{array}{l}5 \\
6\end{array}$ \\
\hline & & & 1. 167 & 4 \\
\hline 730 & 1. 158 & 11 & 1. 158 & 3 \\
\hline 800 & 1. 103 & 3 & $\begin{array}{l}1.116 \\
1.113\end{array}$ & $\begin{array}{l}8 \\
3\end{array}$ \\
\hline & & & 1. 085 & 2 \\
\hline & & & 1. 083 & 2 \\
\hline & & & 1. 081 & 2 \\
\hline
\end{tabular}

$a_{\mathrm{o}}=8.83 \AA$. 
in fair agreement with the one published by Majumdar and Roy [8], the chief difference being that the spacings given in table 2 are consistently slightly greater.

\section{Discussion}

Even the most nearly homogeneous preparations of the new compound contained significant amounts of at least one other phase, most frequently hydrogarnet. This fact makes it impossible to state with certainty that the proposed formula, $2 \mathrm{CaO} \cdot \mathrm{Al}_{2} \mathrm{O}_{3}$. $\mathrm{SiO}_{2} \cdot \mathrm{H}_{2} \mathrm{O}$ actually is correct. The amount of hydrogarnet present was estimated to be 10 percent or less in a few cases. Because of the nearness of the oxide ratios in the two phases, the error introduced in the calculated composition resulting from the presence of 10 percent of hydrogarnet is relatively slight. In consideration of this fact, the ignition loss values lead to the conclusion that the new phase has the formula $2 \mathrm{CaO} \cdot \mathrm{Al}_{2} \mathrm{O}_{3} \cdot \mathrm{SiO}_{2} \cdot \mathrm{H}_{2} \mathrm{O}$. Thus it may be considered a hydrate of gehlenite.

The relative ease of preparation of this gehlenite hydrate raises the question as to why it was not discovered earlier. A reexamination of the x-ray patterns obtained in a previous investigation [7] showed that the isometric phase was unquestionably present in many of the preparations. Unfortunately, it had been mistaken for the ternary compound, $4 \mathrm{CaO} \cdot 3 \mathrm{Al}_{2} \mathrm{O}_{3} \cdot 3 \mathrm{H}_{2} \mathrm{O}$, with which it usually was associated. The x-ray patterns (see table 2) are somewhat similar. Many of the strongest lines are practically coincident, while others are shifted only slightly. It should be noted, also, that diffraction diagrams of different preparations of $4 \mathrm{CaO} \cdot 3 \mathrm{Al}_{2} \mathrm{O}_{3}$. $3 \mathrm{H}_{2} \mathrm{O}$ may vary widely unless great care is taken to avoid orientation effects when mounts are prepared. This fact tended to obscure the significance of the differences that should have been recognized as arising from the presence of another compound. The patterns given in table 2 were obtained on mounts of powders prepared in such a way as to minimize orientation effects; hence the differences between the two patterns are more obvious. Optically, the two phases are also similar, the isometric phase having $n=1.628$, while the $4: 3: 3$ compound is very slightly birefringent, with $n$ (average) $=$ 1.627. Even in crystal habit there is some similarity, in that the cubic phase was observed in some cases to form prisms like those typical of the aluminate.

Owing to these similarities, it was thought that there might be a structural relationship between the two phases. Experiments 27 to 30 (table 1) were intended to permit formation of an intermediate solid solution, but no evidence of such formation was observed.
To the extent that the isometric phase was mistakenly identified as $4 \mathrm{CaO} \cdot 3 \mathrm{Al}_{2} \mathrm{O}_{3} \cdot 3 \mathrm{H}_{2} \mathrm{O}$, the data given and the conclusions drawn in the earlier work cited above [7] need to be modified. ${ }^{2}$

The hydrothermal synthesis of gehlenite at temperatures as low as $450{ }^{\circ} \mathrm{C}$ has been reported recently [9], but no mention was made of a hydrate. The experimental conditions were somewhat different from those of the present work, in that calcium carbonate was used as one of the starting materials, with lime present as a receptor for the carbon dioxide evolved. Nevertheless, from the data given above, it would be expected that the isometric gehlenite hydrate, rather than gehlenite itself, would be formed at $450{ }^{\circ} \mathrm{C}$. The reasons for the apparent conflict in results probably cannot be clarified without additional information regarding experimental details in the work cited.

The existence of the high temperature gehlenite hydrate needs to be taken into account in any future study of phase relations in the system $\mathrm{CaO}-\mathrm{Al}_{2} \mathrm{O}_{3}$ $\mathrm{SiO}_{2}-\mathrm{H}_{2} \mathrm{O}$ at elevated temperatures.

The author wishes to express his thanks to H. E. Swanson and coworkers for the x-ray diffraction diagrams, and to C. R. Robbins for experimental runs in the cold-seal apparatus; also to P. Desautels, of the National Museum, who supplied the specimen of natural gehlenite.

2 The correction applies to the following experiments reported in the paper cited [7]: in table 4 , Nos. 6 and 7 ; in table 6 . Nos. 16,24 , and 26 ; in figure 2 , the poin at the right end of the curve. In each case the phase reported as $4 \mathrm{CaO} \cdot 3 \mathrm{Al}_{2} \mathrm{O}_{3} \cdot 3 \mathrm{H}_{2} \mathrm{O}$ $\left(\mathrm{C}_{4} \mathrm{~A}_{3} \mathrm{H}_{3}\right)$ actually was the isometric phase, $2 \mathrm{CaO} \cdot \mathrm{Al}_{2} \mathrm{O}_{3} \cdot \mathrm{SiO}_{2} \cdot \mathrm{H}_{2} \mathrm{O}$.

\section{References}

[1] F. M. Lea, The chemistry of cement and concrete (Revised Edition of Lea and Desch), (Edward Arnold, London, 1956).

[2] F. W. Locher, Hydraulic properties and hydration of glasses of the system $\mathrm{CaO}-\mathrm{Al}_{2} \mathrm{O}_{3}-\mathrm{SiO}_{2}$, Proc. Fourth International Symposium on the Chemistry of Cement, NBS Monograph 43, pp. 267-276 (1962).

[3] W. Büssem, X-rays and cement chemistry, Proc. Symposium on the Chemistry of Cements, Stockholm, 1938. (See p. 163).

[4] H. zur Strassen and W. Strätling, The reaction between burned kaolin and lime in aqueous solution. II. The reaction products in relation to the system lime-silicaalumina-water. Z. anorg. allgem. Chem. 245, 267-278 (1940).

[5] N. Fratini and T. Turriziani, Contribution to the knowledge of a hydrated calcium silicoaluminate (Strätling's Compound), (in Italian), Ric. Sci. 24, 1654-57 (1954).

[6] C. H. Schmitt, discussion of "Hydration of calcium aluminates and ferrites", by F. E. Jones, Proc. Fourth International Symposium on the Chemistry of Cement (Washington, 1960) p. 244.

[7] E. T. Carlson, Hydrogarnet formation in the system lime-alumina-silica-water, J. Res. NBS 56, 327-335 (1956).

[8] A. J. Majumdar and R. Roy, The system $\mathrm{CaO}-\mathrm{Al}_{2} \mathrm{O}_{3}-$ $\mathrm{H}_{2} \mathrm{O}$, J. Am. Ceram. Soc. 39, 434-442 (1956).

[9] M. Christophe-Michel-Lévy, Hydrothermal synthesis of gehlenite, $\mathrm{Ca}_{2} \mathrm{Al}_{2} \mathrm{SiO}_{7}$, (in French), Compt. rend. 255, 2781-2 (1962). 